\title{
A COMPREHENSIVE STUDY OF DI DIESEL ENGINE PERFORMANCE WITHVEGETABLE OIL: AN ALTERNATIVE BIO-FUEL SOURCE OF ENERGY
}

\author{
A. K. Azad, S. M. Ameer Uddin and M. M. Alam \\ Department of Mechanical Engineering \\ Bangladesh University of Engineering and Technology \\ Dhaka-1000, Bangladesh \\ E-mail: azad_sgfl@yahoo.com
}

\begin{abstract}
This study offers comprehensive details on the use of bio-fuel as a viable and alternative source of energy. The bio-fuel was prepared from vegetable oil, i.e., mustard oil and tested in a diesel engine in both pure form and as a diesel blend. The mustard oil blend proportions were 20\%, 30\%, $40 \%$ and 50\% and named as bio-diesel blends B20, B30, B40 and B50. A fuel-testing laboratory determined the properties of the pure mustard oil fuel and its blends, i.e., density, viscosity, dynamic viscosity, carbon residue, flash point, fire point and calorific value. An assessment of engine performance, i.e., brake horsepower (bhp), brake specific fuel consumption (bsfc), brake thermal efficiency (bte) and brake mean effective pressure (bmep) etc., was carried out for pure diesel, pure mustard and the blends, both in laboratory conditions and under British Standard (BS) conditions. Finally, an analysis and comparison was made of the effects of the various fuels on the different engine properties.
\end{abstract}

Keywords: Mustard oil, bio-diesel, brake thermal efficiency, BSFC, brake horsepower.

\section{INTRODUCTION}

Bio-diesel is the most valuable form of renewable energy for direct use in any existing, unmodified diesel engine. Bio-fuels, generated from crops, create new markets for agricultural products and stimulate rural development, which is especially important for the two-thirds of the people in the developing world who derive their incomes from agriculture. Due to the gradual depletion of world's petroleum reserves and the impact of environmental pollution, there is an urgent need for suitable alternative fuels for use in diesel engines (Kumar et al., 2012; Nakpong and Wootthikanokkhan, 2010; Radha et al., 2011). Thus, vegetable oil is a promising alternative because it is renewable, environmentally friendly and produced easily in rural areas, where there is an acute need for modern forms of energy (Srivasata and Prasad, 2000; Forhad et al., 2009). In recent years, the systematic efforts have been made by several researchers to use as fuel engines. They have also searched for an effective, alternative and renewable fuel source. Mustard is part of the oilseed family, is regarded both as a spice and as an oilseed and is used widely in Eastern parts of India and Bangladesh. The oil, for the most part, contains fatty acids like oleic acids, linoleum acid and erucic acid. It has the lowest amount of saturated fats in its composition and thus is good for the heart and overall health. It can be used to make vegetable oil or be processed further into an essential oil (Berchmans and Hirata, 2008; Altan et al., 2001). 
The oil is obtained by pressing the seeds or through the process of grinding, whereby it is mixed with water and then distilled further. Mustard seeds are composed of $30 \%$ oil. Many countries consider mustard oil as unsuitable for human consumption as it has a high content of a substance known as erucic acid, which is harmful to the body but now mustard oils with lower erucic acid are also available (Huzayyin et al., 2004).

Vegetable oils are widely produced from a variety of products. Because these oils are of plant origin, the plants themselves consume large quantities of $\mathrm{CO}_{2}$ derived from the burning of these oils. Therefore, these oils do not contribute to the absolute deposit of $\mathrm{CO}_{2}$. They are renewable in nature and environmentally sound due to their minimum net effect on pollution (Khan et al., 2006; Lin et al., 2006). Vegetable oils are suitable for cooking purposes or as a fuel. The main fact that determines the usage of the oil is the quality. Generally, good quality oil is used for cooking purposes. However, vegetable oil can be used in most old diesel engines but only in a warm atmosphere. In most countries, production of vegetable oil is for biodiesel.

The concept of using vegetable oils as a substitute for diesel fuel is an old one, which dates back around 70 years. Since then very little has been done regarding its use as diesel engine fuel primarily due to abundant availability of diesel (Naik et al., 2008). Moreover, there was no serious complaint against the use of diesel because its adverse environmental effects were not apparent at that time. In recent years, vegetable oils have received considerable attention for use in diesel engines, because of their environmental friendliness and renewable nature. As a result, international interest in the use of vegetable oils as diesel engine fuel has been renewed (Radwan et al., 2007; Srivasata and Prasad, 2000).

Investigations established that vegetable oils could meet the entire diesel demand of the agricultural sector in the northern region of Thailand, if $10 \%$ of cultivatable land went into vegetable oil crop production (Srivasata and Prasad, 2000; Forhad et al., 2009). Thus, the country could even be self-sufficient in fuel. Among the oils studied, groundnut oil proved to be the most attractive due to its high energy yield, favourable economic suitability and short growth period. Soybean was also established as prospective engine fuel because of its general availability and high economic suitability (Freedom et al., 1984).

The study of Yosimoto et al. (2001) reflects the Japanese experience using different vegetable oil blends with kerosene to improve the performance of a small high-speed diesel engine under high load conditions. They worked with a single cylinder/direct injection, 4-stroke, air-cooled diesel engine, applying four blends (20, 40, 60 and $80 \%$ by volume) of soybean oil with kerosene, as well as rapeseed oil with kerosene and compared the results with that of pure diesel fuel. They also studied the spray distribution of each blend in the atmosphere using 4-hole nozzle injector engines. The results show that a blend of $20 \%$ vegetable oil with $80 \%$ kerosene by volume, improves the thermal efficiency of the test engine under high load. Therefore, vegetable oil blends of $20 \%$ to $40 \%$ are recommended as successful alternatives to diesel. 


\section{METHODS OF DETERMINING BIO-FUEL PROPERTIES}

Figure 1 in the above section illustrates the method of preparing mustard oil from its oil seed. This section discusses the properties of the fuel and blends. The fuel properties measured are: density, viscosity (kinematic viscosity and dynamic viscosity), volatility, carbon residue, ash content, heating value or calorific value, flash point and fire point and these properties for mustard oil are presented in Table 1.

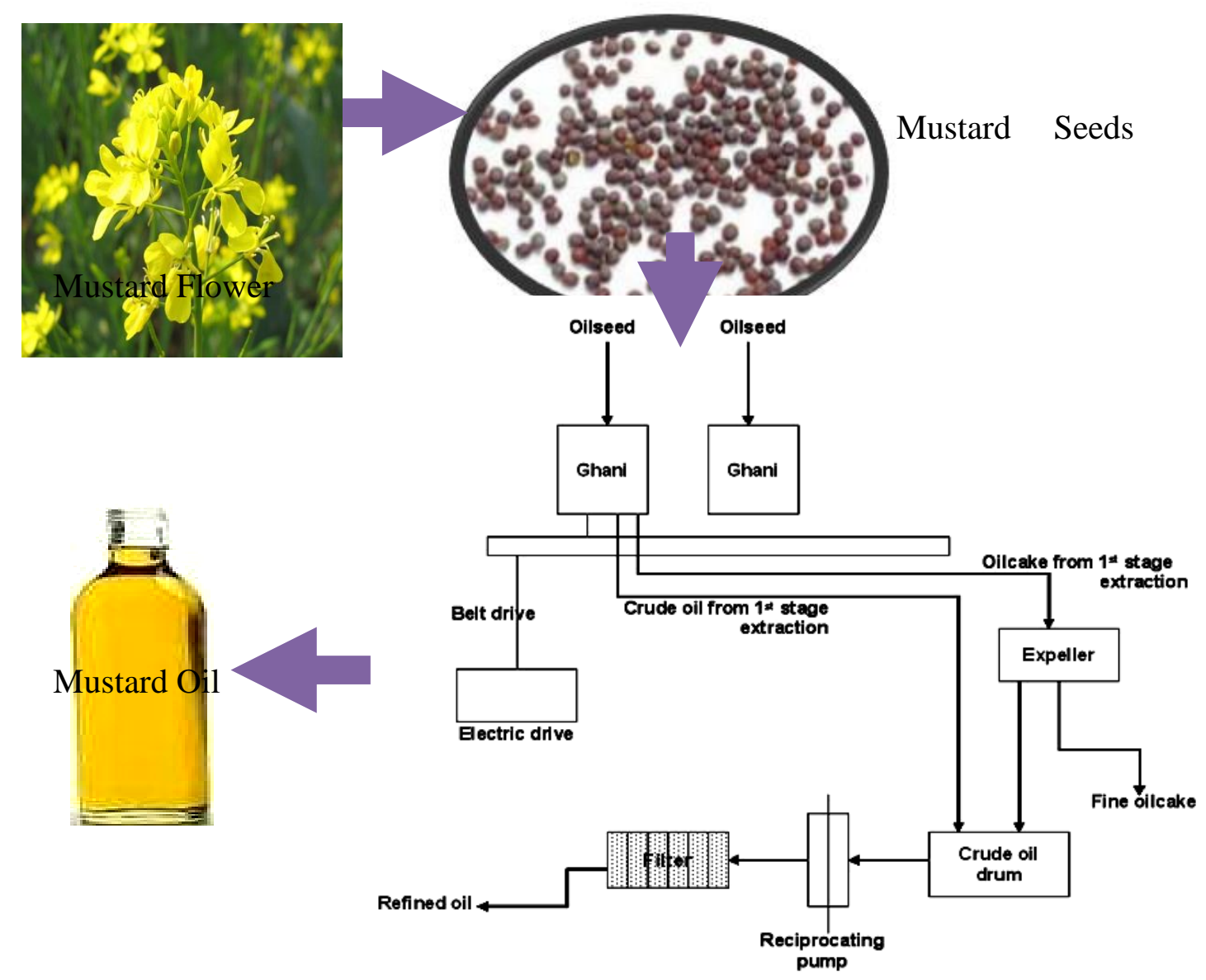

Figure 1. Flow diagram of typical mustard oil processing

Figure 2 shows the colour of the different bio-diesel blends from left to right B20, B30, B40, B50, B100/pure mustard oil and pure diesel, respectively. The properties of these bio-fuel blends were tested in the fuel-testing laboratory and the results are presented in Table 2 . The heating value indicates the energy density of the fuel. In our study, the ASTM 2382 method has been applied to measure the heating value of bio-diesel and the blends. Table 2 shows the heating value of diesel, neat biodiesel and their blends in $\mathrm{MJ} / \mathrm{Kg}$. Figure 3 shows that diesel fuel has a heating value of about $44 \mathrm{MJ} / \mathrm{Kg}$ and that the heating value of the fuel decreases as we choose higher blends of bio-diesel. The calorific value or heating value is a very important property of the fuel. 
Table 1. Properties of mustard oil

\begin{tabular}{|c|c|c|c|}
\hline SL. No & Property and Standards & Unit & Value \\
\hline 1. & Density@ $31{ }^{\circ} \mathrm{C}(\mathrm{ASTM}$ D4052-11) & $\mathrm{kg} / \mathrm{m}^{3}$ & 925.24 \\
\hline 2. & Density@70 ㄷ (ASTM D4052-11) & $\mathrm{kg} / \mathrm{m}^{3}$ & 900.24 \\
\hline 3. & Density@100C (ASTM D4052-11) & $\mathrm{kg} / \mathrm{m}^{3}$ & 885.6 \\
\hline 4. & Specific Gravity（ASTM D5453-09) & - & 0.941 \\
\hline 5. & $\begin{array}{l}\text { Kinematic Viscosity @ } 31^{\circ} \mathrm{C} \\
\text { (ASTM D2161-79) }\end{array}$ & $\begin{array}{c}\mathrm{mm}^{2} / \mathrm{sec} \\
\text { (Centistokes) }\end{array}$ & 63.40 \\
\hline 6. & $\begin{array}{l}\text { Kinematic Viscosity @ } 70{ }^{\circ} \mathrm{C} \\
\text { (ASTM D2161-79) }\end{array}$ & $\mathrm{mm}^{2} / \mathrm{sec}$ & 21.85 \\
\hline 7. & $\begin{array}{l}\text { Kinematic Viscosity @ } 100{ }^{\circ} \mathrm{C} \\
\text { (ASTM D2161-79) }\end{array}$ & $\mathrm{mm}^{2} / \mathrm{sec}$ & 9.79 \\
\hline 8. & $\begin{array}{l}\text { Dynamic Viscosity @ } 31^{\circ} \mathrm{C} \\
\text { (ASTM D7042-11a) }\end{array}$ & $\mathrm{cP}$ & 58.66 \\
\hline 9. & $\begin{array}{l}\text { Dynamic Viscosity @ } 70{ }^{\circ} \mathrm{C} \\
\text { (ASTM D7042-11a) }\end{array}$ & $\mathrm{cP}$ & 19.67 \\
\hline 10. & $\begin{array}{l}\text { Dynamic Viscosity @ } 100 \text { C } \\
\text { (ASTM D7042-11a) }\end{array}$ & $\mathrm{cP}$ & 8.67 \\
\hline 11. & $\begin{array}{l}\text { Calorific Value or Heating value } \\
\text { (ASTM 2382) }\end{array}$ & $\mathrm{MJ} / \mathrm{Kg}$ & 39.51 \\
\hline 12. & Carbon Residue (ASTM D189-81) & gm & 0.037 \\
\hline 13. & $\begin{array}{l}\% \text { of Carbon Residue } \\
\text { (ASTM D189-81) }\end{array}$ & $\%$ & 0.37 \\
\hline 14. & Flash Point (ASTM D93-85) & ${ }^{\circ} \mathrm{C}$ & 310 \\
\hline 15. & Fire Point (ASTM D92-11) & ${ }^{\circ} \mathrm{C}$ & 350 \\
\hline
\end{tabular}

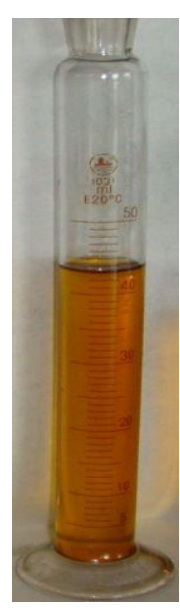

B20

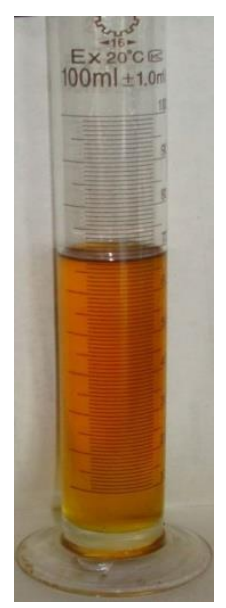

B30

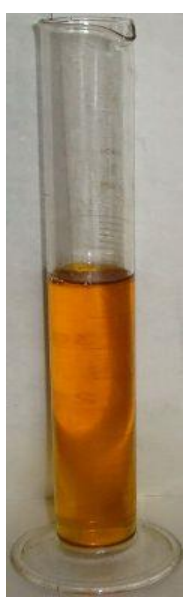

B40

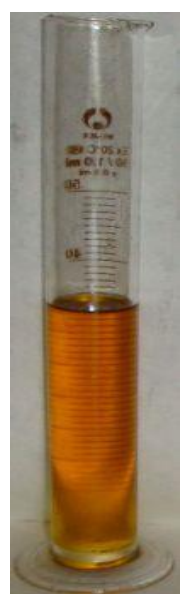

B50

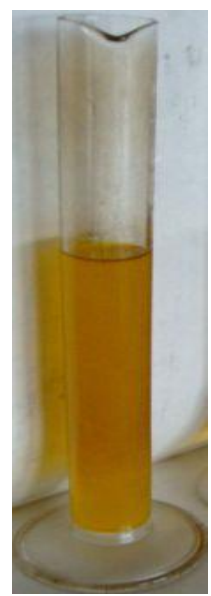

B100

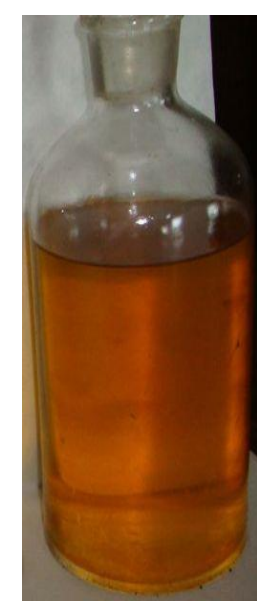

Pure

Diesel

Figure 2. Colour of different biodiesel blends, pure mustard oil and diesel. 
Table 2. Properties of different biofuel blends, mustard oil and pure diesel.

\begin{tabular}{|c|c|c|c|c|c|c|c|}
\hline \multirow[b]{2}{*}{ Properties and Standards } & \multirow[b]{2}{*}{ Unit } & \multicolumn{6}{|c|}{ Value for different biofuel blends } \\
\hline & & B20 & B30 & B40 & B50 & $\begin{array}{l}\text { B100 or } \\
\text { Mustard }\end{array}$ & $\begin{array}{l}\text { Pure } \\
\text { Diesel }\end{array}$ \\
\hline $\begin{array}{l}\text { Density } 31^{\circ} \mathrm{C} \\
(\text { ASTM D4052-11) }\end{array}$ & $\mathrm{kg} / \mathrm{m}^{3}$ & 840.96 & 847.96 & 855.64 & 863.84 & 925.24 & $\begin{array}{c}825.9 \\
6\end{array}$ \\
\hline $\begin{array}{l}\text { Specific Gravity } \\
\text { (ASTM D5453-09) }\end{array}$ & - & 0.904 & 0.910 & 0.915 & 0.920 & 0.941 & 0.899 \\
\hline $\begin{array}{l}\text { Kinematic Viscosity } 31{ }^{\circ} \mathrm{C} \\
\text { (ASTM D2161-79) }\end{array}$ & $\begin{array}{c}\mathrm{mm}^{2} / \mathrm{s} \\
\mathrm{ec}\end{array}$ & 8.113 & 11.01 & 14.1 & 18.51 & 63.40 & 3.96 \\
\hline $\begin{array}{l}\text { Dynamic Viscosity @ } 31{ }^{\circ} \mathrm{C} \\
\text { (ASTM D7042-11a) }\end{array}$ & $\mathrm{cP}$ & 6.822 & 9.33 & 12.064 & 15.989 & 58.66 & 3.27 \\
\hline $\begin{array}{l}\text { Calorific value } \\
(\text { ASTM 2382) }\end{array}$ & $\begin{array}{c}\mathrm{MJ} / \mathrm{K} \\
\mathrm{g}\end{array}$ & 42.65 & 42.21 & 42.18 & 41.97 & 39.51 & 44.00 \\
\hline $\begin{array}{l}\text { Flash Point } \\
\text { (ASTM D93-85) }\end{array}$ & ${ }^{\circ} \mathrm{C}$ & 85 & 85 & 100 & 130 & 310 & 72 \\
\hline $\begin{array}{l}\text { Fire Point } \\
\text { (ASTM D92-11) }\end{array}$ & ${ }^{\circ} \mathrm{C}$ & 100 & 110 & 120 & 110 & 350 & 210 \\
\hline
\end{tabular}

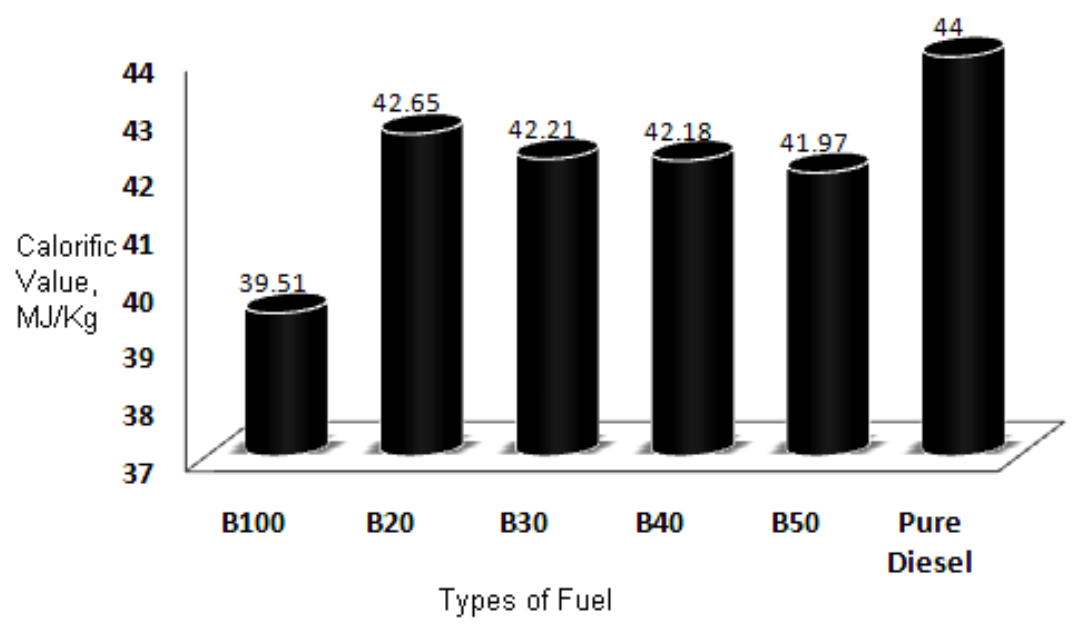

Figure 3. Lower calorific value (LCV) for different bio-fuels.

\section{EXPERIMENTAL SETUP}

Figure 4 shows schematic diagram of the experimental setup with hydraulic dynamometer. In this experiment a single cylinder, water-cooled, 4-stroke, directinjection (DI) diesel engine (specification Table-3) was used for performance testing. The RPM was measured directly from the tachometer attached by the dynamometer. Figure 5 shows the test engine mounted on dynamometer bed. Figure 6 also shows the dynamometer coupling with test engine. The fuel injection timing was set at 24 ${ }^{\circ}$ BTDC. A water brake dynamometer from Tokyo Meter Co. Ltd., model no.TFJ-250L simulated artificial loads and tested engine performance. The dynamometer varied the load on the engine using variable water flow as well as variable impeller blade angles. A non-contact magnetic induction tachometer and a Wheatstone bridge load cell measured speed and torque. 
Table 3. Test Engine specifications

\begin{tabular}{cll}
\hline SL. & Items & Engine Data \\
\hline 1. & Model & S195G \\
2. & Method of starting & Hand starting \\
3. & Engine Type & $\begin{array}{l}\text { Single cylinder, 4-stroke, Horizontal, Direct } \\
\text { Injection }\end{array}$ \\
4. & Cylinder Bore & $95 \mathrm{~mm}$ \\
5. & Piston stroke/ Stroke & $115 \mathrm{~mm}$ \\
6. & Swept Volume & $85 \mathrm{cc}$ \\
7. & Nominal speed & $2000 \mathrm{rpm}$, Anti-clockwise \\
8. & Nominal power & $9 \mathrm{KW}$ \\
9. & Compression ratio & $1: 20$ \\
10. & Specific fuel & Less or equal 258.4 gm/kw-hr or 192.76 gm/BHP-hr \\
& consumption & \\
11. & Cooling system & Water cooled condenser type, Thermosyphon with \\
& & suction fan \\
12. & Fuel and Lube oil filter & Present \\
\hline
\end{tabular}

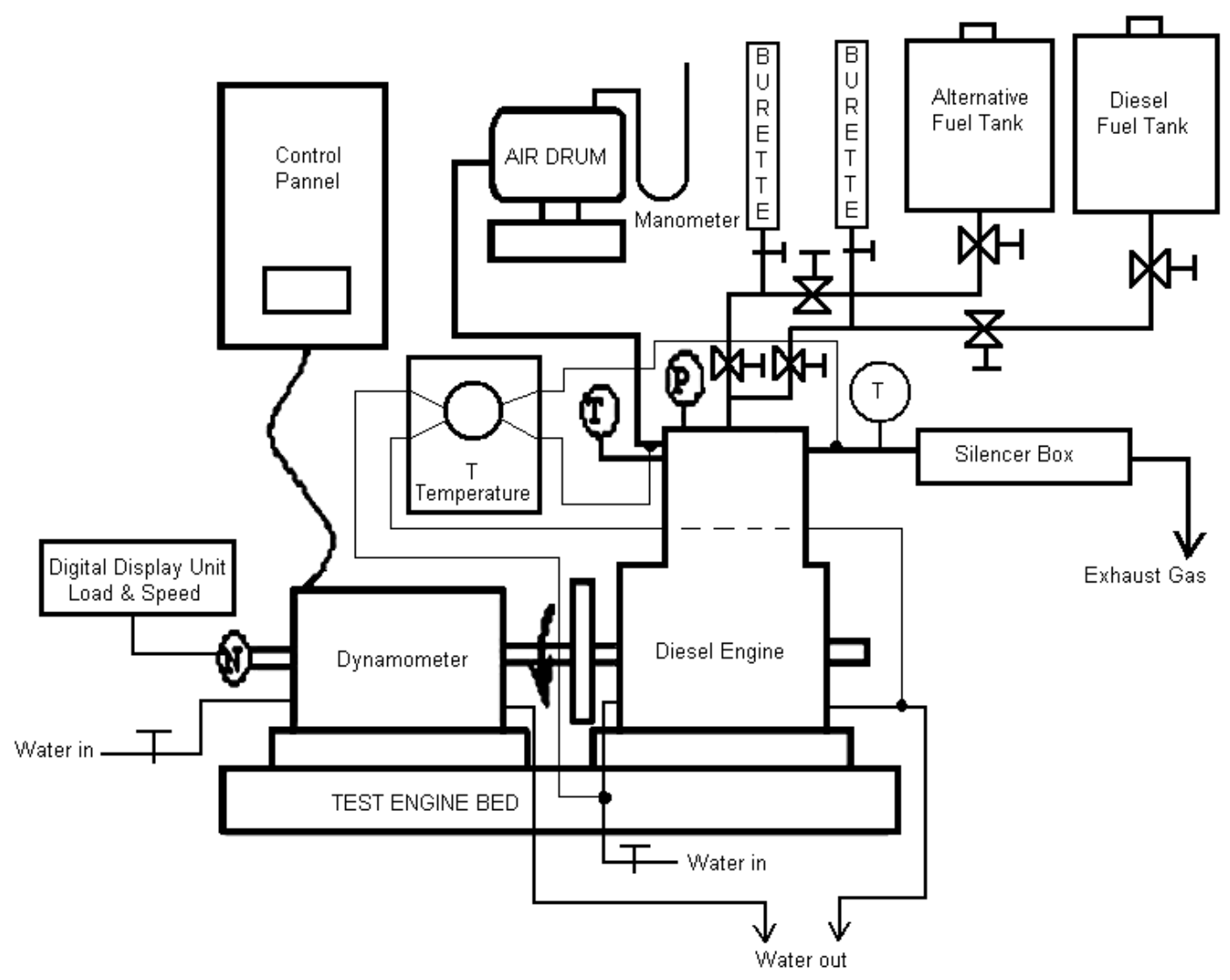

Figure 4. Schematic diagram of the experimental setup with hydraulic dynamometer. 


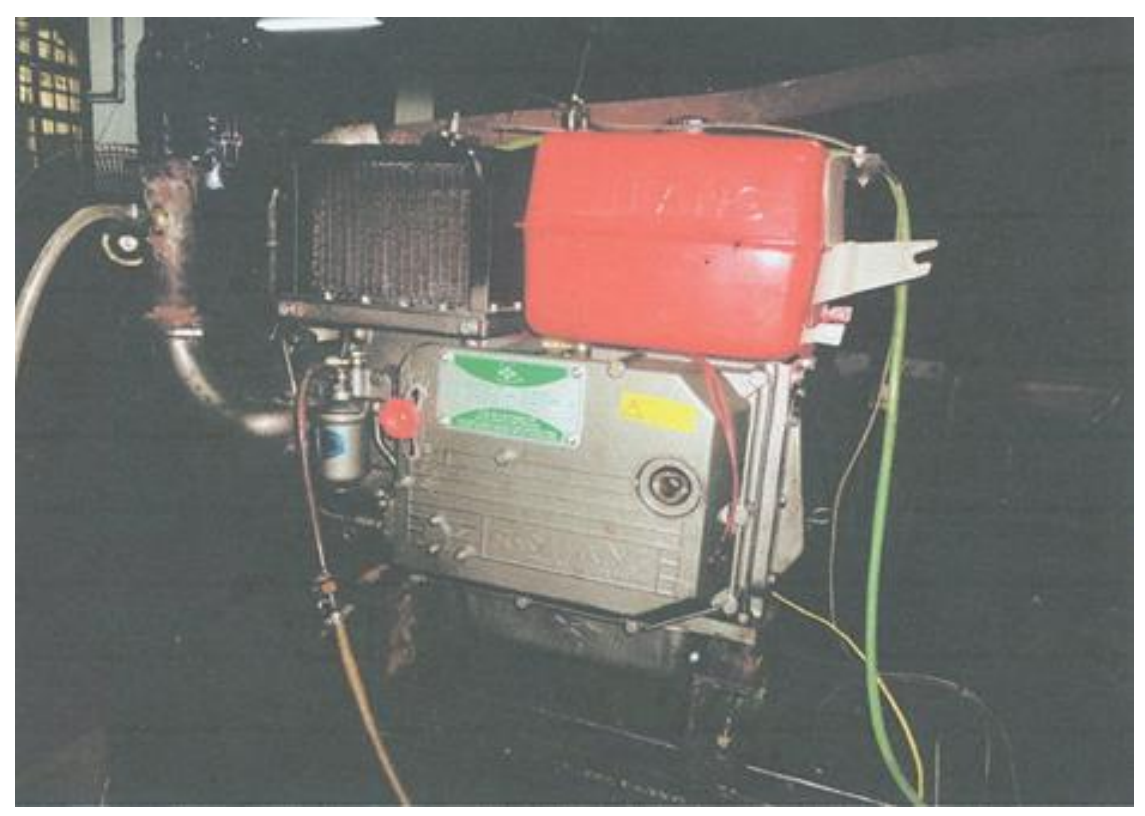

Figure 5. Test engine mounted on dynamometer bed.

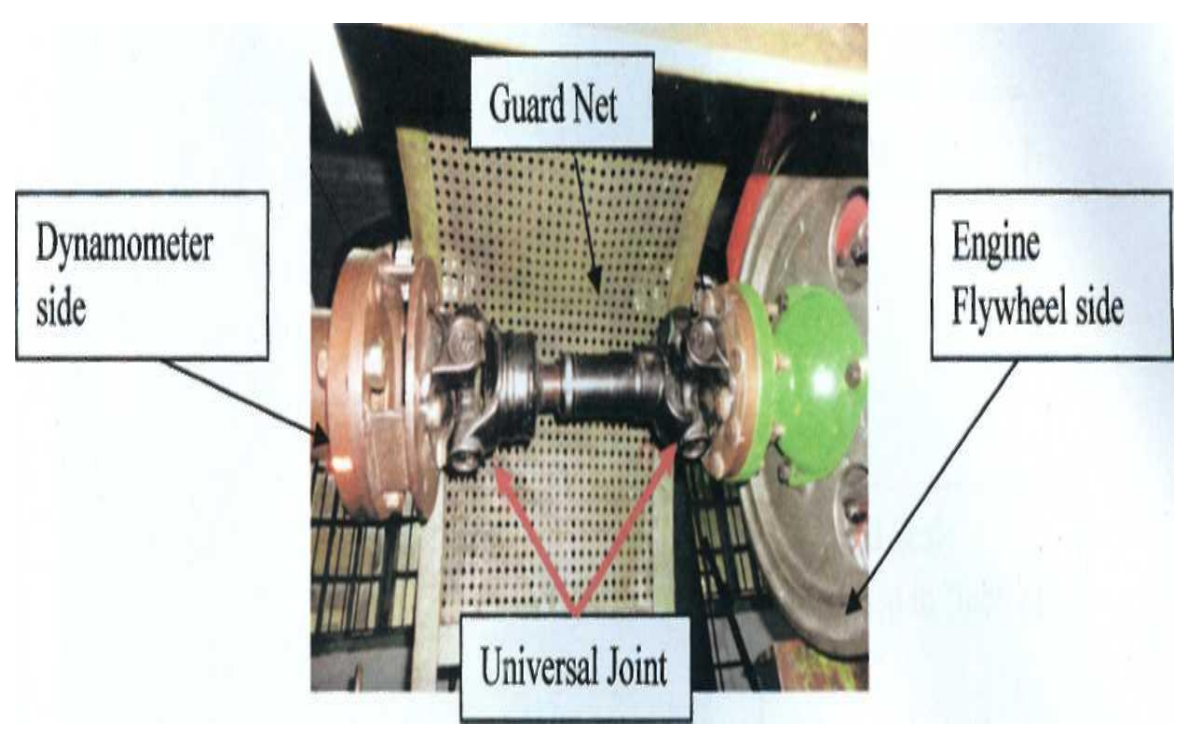

Figure 6. Dynamometer coupling with test engine.

\section{RESULTS AND DISCUSSION}

Figure 7 shows the variation of brake specific fuel consumption (bsfc) with engine load for different bio-fuel blends. The bsfc was calculated as fuel consumption divided by the rated power output of the engine. The curve shows that bsfc is higher at low loads and decreases with increased loads for the different bio-diesel blends. The bsfc also increases with the increase in percentage of blend i.e., B20 to B100. This is mainly due to the relationship between the volumetric fuel injection system, specific gravity, viscosity and heating value. Therefore, in order to produce the same amount of energy as conventional diesel fuel, a greater bio-diesel blend is required, due to its higher density and lower heating value. Additionally, as the blends have different 
viscosities to diesel fuel, bio-diesel causes poor atomisation and mixture formation and thus, increases the fuel consumption rate in order to maintain the power. The lowest bsfc is obtained for B30 (186.6 g/bhp-hr) at $10.5 \mathrm{~kg}$ load and this blend maintains the lowest bsfc compared with any other bio-diesel blend. The second lowest bsfc obtained is for B20 (200 g/bhp-hr) at the same load. Therefore, B30 is the best blend sample for this test experiment.

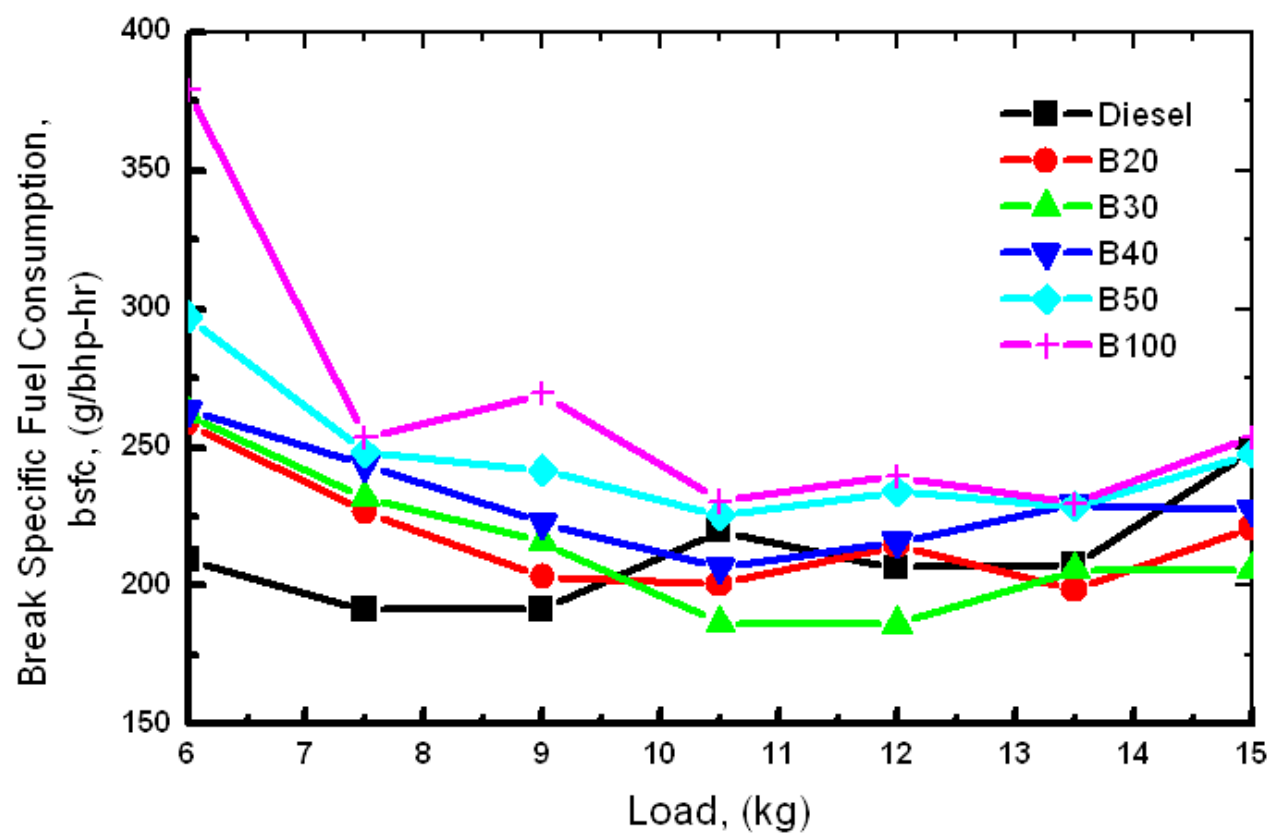

Figure 7. Variation of brake specific fuel consumption with engine load.

The bsfc is a measure of the overall efficiency of an engine. It is also inversely proportional to the thermal efficiency. Therefore, a lower value of bsfc indicates a higher overall efficiency of an engine. Figure 8 presents the variation of brake thermal efficiency (BTE) with engine load. The bte of the engine is observed to increase with an increase in the load with a maximum for B30 (52.93\%) at $12 \mathrm{~kg}$ of load. Higher blends of B40 and above have lower thermal efficiency than B20 and B30 due to lower calorific value, higher viscosity and poor atomization characteristics. The mean effective pressure is the average pressure developed on the piston head over a cycle in the combustion chamber of the engine, which measures the capacity of the engine to do work. Figure 9 shows the variation of brake mean effective pressure for the different bio-fuel blends. A small variation of brake mean effective pressure from pure diesel fuel was observed during the experiment.

Figure 10 shows the relationship between lube oil temperature and engine load for the different fuel and bio-fuel blends. The lube oil temperature increases with an increase of engine load and the highest lube oil temperature was found for B40 $\left(84{ }^{\circ} \mathrm{C}\right)$ at full load conditions. This phenomenon can be attributed to the preheating of the B40 fuel at $70{ }^{\circ} \mathrm{C}$. However, there is not a wide variance in the lube oil temperature for diesel fuel and bio-diesel blends, which indicates that SAE-40 lube oil is suitable for engines running on bio-diesel. 


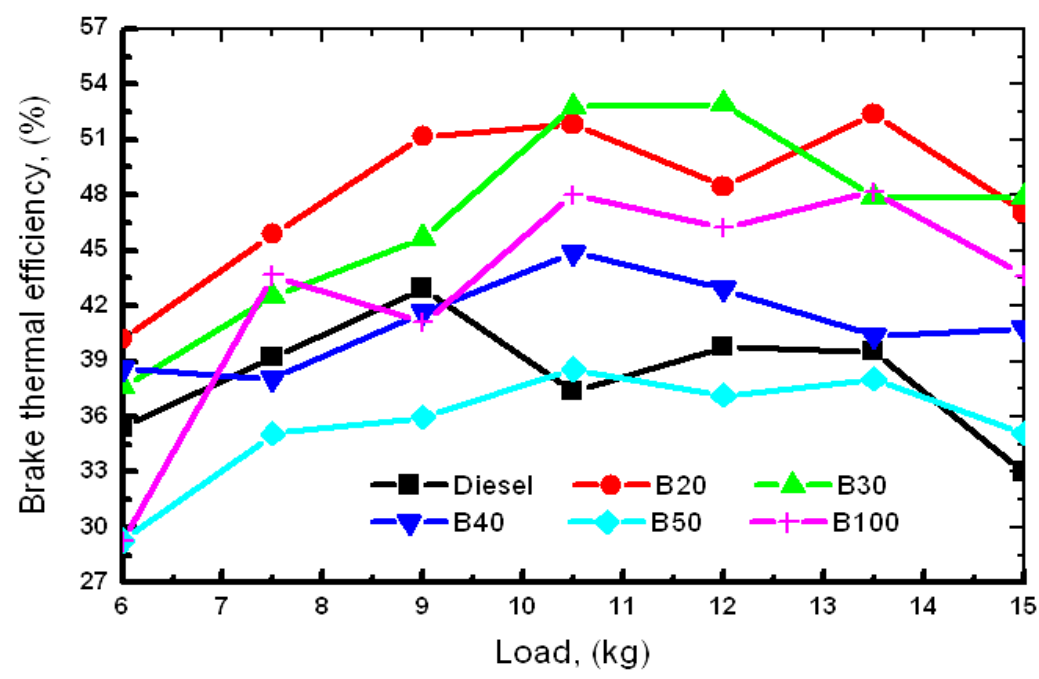

Figure 8. Variation of brake thermal efficiency with engine load

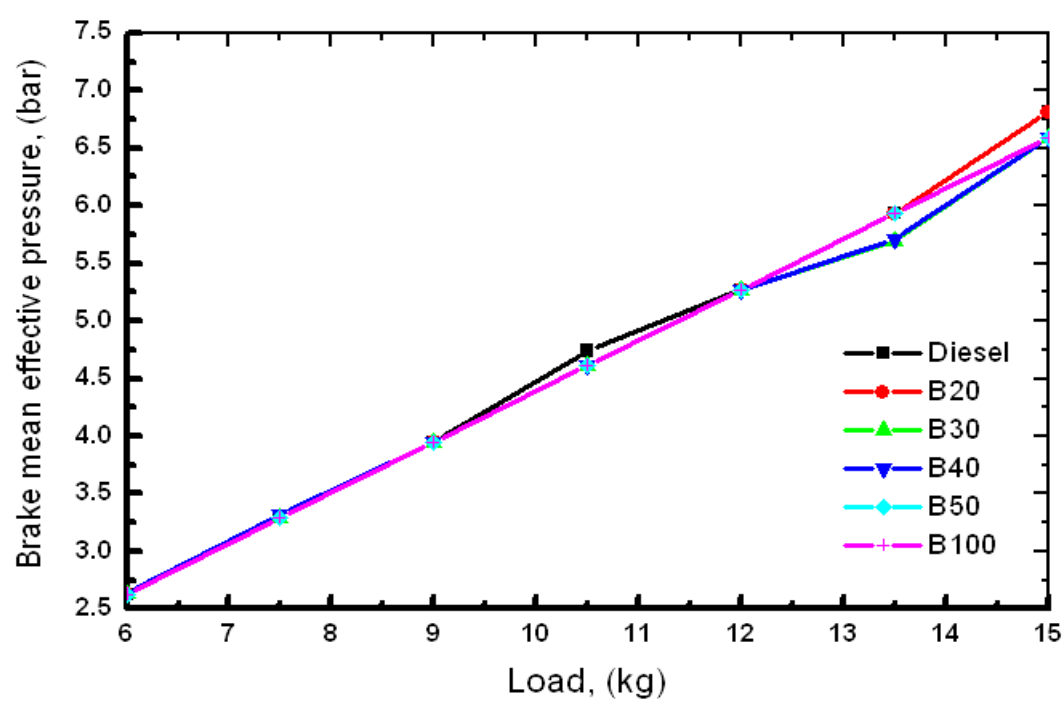

Figure 9. Variation of brake mean effective pressure with engine load.

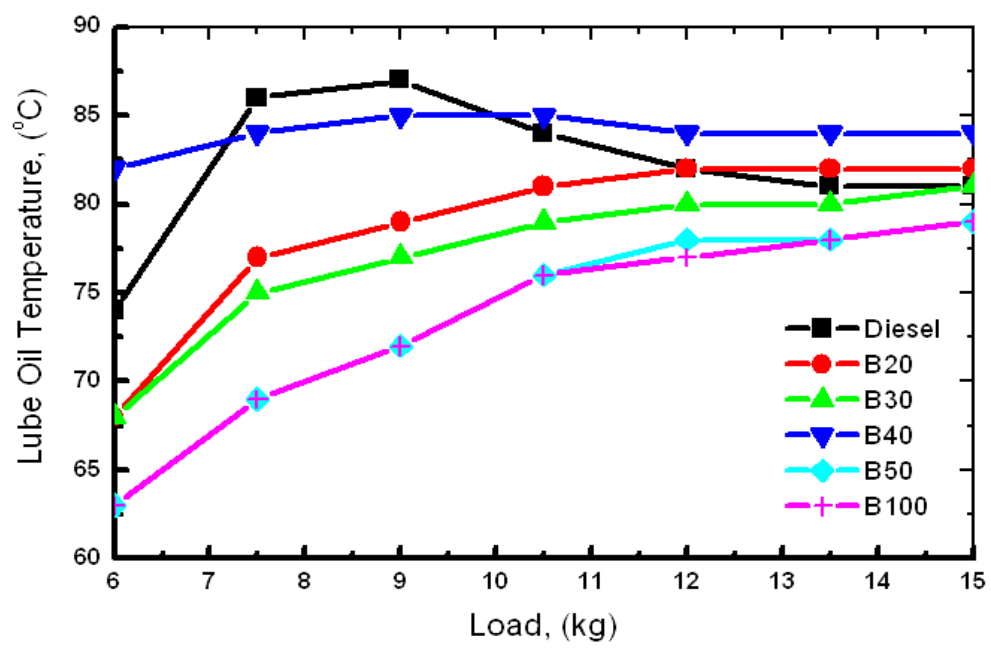

Figure 10. Variation of engine lube oil temperature with load. 
Figure 11 represents the variation of exhaust gas temperature with engine load for the different fuels. From the curve, it can be observed that initially the exhaust gas temperature is low with little variation among the fuels. B100 or pure mustard oil has a higher exhaust gas temperature than all the other bio-diesel blends. At starting conditions, high exhaust gas temperature but low power output for bio-diesel blends indicates late burning of the high proportion bio-diesel. This would increase the heat loss making the combustion a less efficient. At higher load conditions, B40 has the lowest exhaust gas temperature compared with the other fuels.

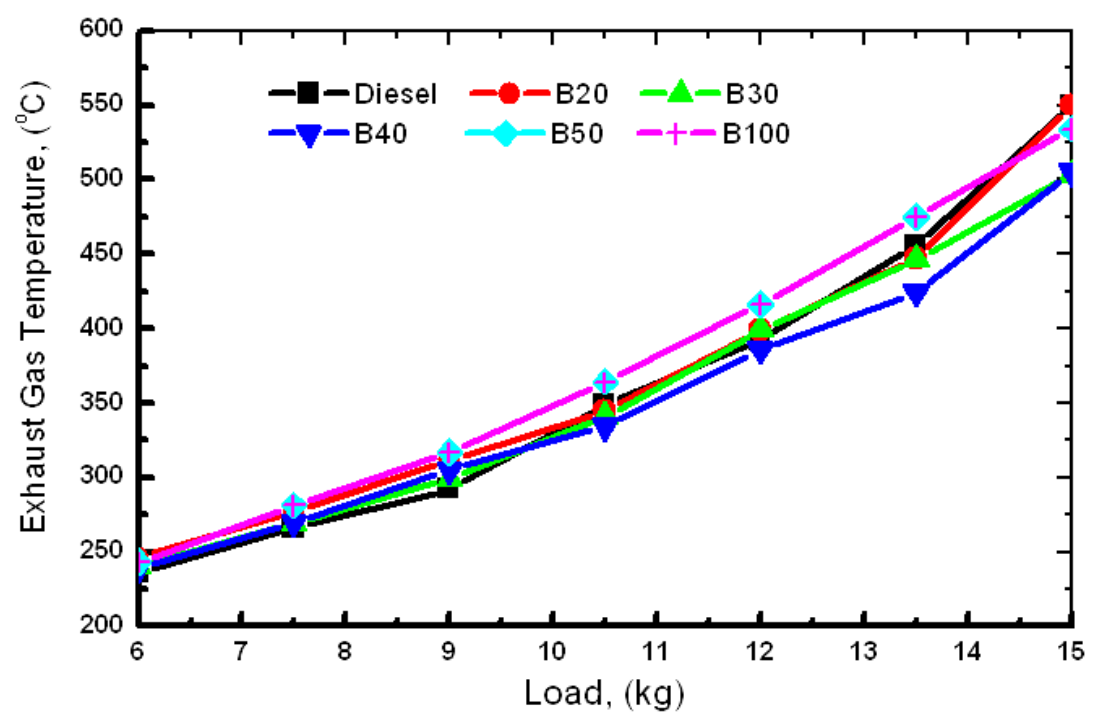

Figure 11. Variation of exhaust gas temperature with engine load.

\section{CONCLUSIONS}

With regard to the experimental study for vegetable oil as a renewable alternative source of fuel for diesel engines, the following conclusions are drawn:

i) Bio-diesel can be produced from mustard oil as an alternative fuel for DI diesel engines.

ii) The calorific value of the bio-diesel blends decreases with the increase of vegetable oil percentage and the lowest heating value was obtained for B100 or pure mustard oil.

iii) At starting conditions or low load conditions, the bio-fuel blends have a higher bsfc than diesel. However, for B30, after $10.0 \mathrm{~kg}$ load, the bsfc becomes lower than for any other fuel in the experiment.

iv) The brake thermal efficiency for B20 and B30 becomes better than other fuel blends at this engine operating condition.

v) The lube oil temperature decreases with the increase of bio-diesel blends except B40 but exhaust gas temperature increases with the increase of bio-diesel blends.

vi) A small variation in the brake mean effective pressure was observed for the different bio-diesel blends in relation to diesel fuel.

vii) Throughout the experiment, $\mathrm{B} 20$ and $\mathrm{B} 30$ give better performance than the other bio-diesel blends. Finally, it is possible to run diesel engine with bio-diesel blends. 


\section{REFERENCES}

Altan, R., Cetinkaya, S. and Yucesu, H.S. 2001. The potential of using vegetable oil fuels as fuel for diesel engines. Energy Conversion and Management, 42(5): 529-538.

Berchmans, H.J. and Hirata, S. 2008. Biodiesel production from crude Jatropha curcas L. seed oil with a high content of free fatty acids. Bioresource Technology, 99(6): 1716-1721.

Forhad, A., Rowshan, A.R., Habib, M.A. and Islam, M.A. 2009. Production and performance of biodiesel as an alternative to diesel. International Conference on Mechanical Engineering, ICME09-TH-30, pp. 1-6.

Freedman, B., Pryde, E.H. and Mounts, T.L. 1984. Variables affecting the yields of fatty esters from transesterified vegetable oils. Journal of the American oil Chemists' Society, 61(10): 1638-1643.

Huzayyin, A.S., Bawady, A.H., Rady, M.A. and Dawood, A. 2004. Experimental evaluation of diesel engine performance and emission using blends of jojoba oil and Diesel fuel. Energy Conversion and Management, 45(13-14): 20932112.

Khan, M.Y., Khan, S.Y. and Ahmad, N. 2006. Performance characteristics of compression ignition engine when operated on preheated Neem oil. Proceeding of International Conference on Advances in Mechanical Engineering, Punjab,pp.

Kumar, S., Chaube, A. and Jain, S.K. 2012. Experimental investigation of C.I. Engine Performance Using Diesel Blended with Jatropha Bio-diesel. International Journal of Energy and Environment, 3(3): 471-484.

Lin, C.Y., Chen, L.W. and Wang, L.T. 2006. Correlation of black smoke and nitrogen oxides emissions through field testing of in-use diesel vehicles. Environmental Monitoring and Assessment, 116(1-3): 291-305.

Naik, M., Meher, L.C., Naik, S.N. and Das, L.M. 2008. Production of biodiesel from high free fatty acid Karanja (Pongamia pinnata) oil. Biomass and Bioenergy, 32(4): 354-357.

Nakpong, P. and Wootthikanokkhan, S. 2010. Optimization of biodiesel production from Jatropha curcas L. oil via alkali-catalyzed methanolysis. Journal of Sustainable Energy \& Environment, 1: 105-109.

Radha, K.K., Sarada1, S.N., Rajagopal, K. and Nagesh, E.L. 2011. Performance and emission characteristics of CI engine operated on vegetable oils as alternate fuels. International Journal of Automotive and Mechanical Engineering, 4: 414-427.

Radwan, M.S., Ismail, M.A., Elfeky, S.M.S. and Abu- Elyazeed, O.S.M. 2007. Jojoba methyl ester as a diesel fuel substitute: Preparation and characterization. Applied Thermal Engineering, 27(: 314-322.

Srivasata, A. and Prasad, R. 2000. Triglyceride based diesel Fuels. Renewable and sustainable Energy Reviews, 4(2): 111-133.

Yosimoto, Y., Onodera, A. and Tamaki, H. 2001. Production and emission characteristics of diesel engine fuelled by vegetable oils. The Society of Automotive Engineers, No. 2001-01-1807. 